University for Business and Technology in Kosovo

UBT Knowledge Center

UBT International Conference

2012 UBT International Conference

Nov 2nd, 9:00 AM - Nov 3rd, 5:00 PM

\title{
The Determinants of Real Exchange Rate in Albania
}

\author{
Edmira Cakrani \\ University of Vlora, edmira.cakrani@yahoo.com \\ Pranvera Resulaj \\ University of Vlora, pranvera.resulaj@univlora.edu.al
}

Follow this and additional works at: https://knowledgecenter.ubt-uni.net/conference

Part of the Business Commons

\footnotetext{
Recommended Citation

Cakrani, Edmira and Resulaj, Pranvera, "The Determinants of Real Exchange Rate in Albania" (2012). UBT International Conference. 33.

https://knowledgecenter.ubt-uni.net/conference/2012/all-events/33

This Event is brought to you for free and open access by the Publication and Journals at UBT Knowledge Center. It has been accepted for inclusion in UBT International Conference by an authorized administrator of UBT Knowledge Center. For more information, please contact knowledge.center@ubt-uni.net.
} 


\title{
THE DETERMINANTS OF REAL EXCHANGE RATE IN ALBANIA
}

\author{
Edmira Cakrani ${ }^{1}$, Pranvera Resulaj ${ }^{1}$ \\ ${ }^{I}$ Department of Economics, University of Vlora “Ismail Qemali”, Albania. \\ edmira.cakrani@yahoo.com \\ pranvera.resulaj@univlora.edu.al
}

\begin{abstract}
RER is one of the most important economic variables, especially in today's conditions of integration processes, the removal of trade barriers and increasing direct competition between countries. RER behavior affects the economy in microeconomic terms defining the allocation of resources between the tradable sector and the non-tradable sector. RER affects economy also in macroeconomic terms, through its impact on key economic variables, such as economic growth, employment and inflation. But RER itself is affected by economic variables. The aim of this paper is to examine the economic fundamentals that determine the level of the RER in Albania and the extent of influence of each of them. A log linear regression model is used to assess the impact of relative price of non-tradable to tradable goods, openness, foreign direct investment, remittances, real GDP per capita and government expenditures in defining the level of RER. The Johansen cointegration test suggests a relationship among the variables. The finding is that trade openness and real income per capita are insignificant variables, while the others are important in defining the level of RER.
\end{abstract}

Keywords: real exchange rate, unit root, cointegration.

\section{INTRODUCTION}

Real exchange rate is one of the most important macroeconomic variables and its management poses a challenge for policymakers. Change affects the broad allocation of resources in the economy, between tradable and non-tradable products. Real exchange rate is considered also as a key indicator of a country's competitiveness. A real overvaluation of the exchange rate is interpreted as a decline in price competitiveness, while a real exchange rate under valuated leads to a faster economic growth (Rodrik, 2008). A real rate consistently overestimated is an early indicator of possible currency crisis (Kaminsky and Reinhart, 1999). In a study on Albania, Mancellari and others (1999) showed that changes in the exchange rate precede inflation. Exchange rate fluctuations in developing countries can affect aggregate demand and investment expansion (Frenkel, 2004), while an overvalued currency negatively affects employment (Hua, 2011).

The strategic objective of Albania is the accession to the European Union, where the last stage of this process is the monetary union. This union requires as precondition the exchange rate stability, at a rate, which should reflect the best possible assessment of the equilibrium exchange rate, based on a wide range of economic indicators (ECB, 2003). Therefore, the main objective of policy rate should be correction of the real exchange rate misalignement.

The objective of this paper is to present a model for determination of the real exchange rate in Albania. Since Albania's main trading partners are Italy, Greece and Germany, this paper will study the real exchange rate against the euro. Due to lack of data, the study will include the period 2004-2011 with quarterly data.

\section{REAL EXCHANGE RATE DEFINITION}

In the economic literature the real exchange rate RER cannot be defined in a single way. Some economists define it as the ratio of the price of tradable products to non-tradable products, also called the internal rate of real exchange rate 
$\operatorname{RER}=\frac{P^{T}}{P^{J T}}$

Where $P^{T}$ represents the level of prices for tradable sector products and $P^{J T}$ represents the level of price for non-tradable sector products. Tradable products are products that are produced domestically and consumed at home and abroad. For small countries, for example Albania, with little weight in the international market, the price of these products generally taken for granted. Non-tradable products are products that are produced domestically and consumed within the country so do not cross international borders. This is a microeconomic definition of the exchange rate, giving signals for resource allocation in the economy between the two sectors.

Other economists provide a macroeconomic definition of RER, as product of nominal exchange rate with the ratio of foreign prices to domestic prices, also called the real foreign exchange rate:

$\mathrm{RER}=\mathrm{E} \frac{P^{*}}{P}$

Where $\mathrm{P}^{*}$ represents the foreign price level, $\mathrm{P}$ represents the price level in the country, while E represents the nominal exchange rate, which may be bilateral in the case of bilateral RER, or may be multilateral in the case of the effective RER. So RER might otherwise be seen as the ratio of domestic prices to foreign prices, expressed in the same currency. Both foreign and domestic price index, express the level of the consumer basket prices, which has in its composition tradable products as well as non-tradable products. For this reason in this paper will analyze the real foreign exchange rate, because it includes the real internal exchange rate.

\section{FUNDAMENTAL VARIABLES DETERMINING THE REAL EXCHANGE RATE.}

In this paper, as fundamental variables that determine the real exchange rate will be analyzed: real GDP per capita, foreign direct investment, the ratio of tradable to non-tradable products, trade openness, remittances and government expenditures. Data will be obtained by the Bank of Albania, Eurostat and the Ministry of Finance, Albania. Variables are defined as follows:

The real effective exchange rate, will be calculated as a weighted geometric average of the price index of partner countries compared to domestic prices.

$\mathrm{RER}=\mathrm{E} \frac{P^{*}}{P}=\prod_{i=1}^{I}\left[S_{i} \frac{P_{i}^{*}}{P}\right]^{w^{i}}$

Where $S_{i}$ is the nominal exchange rate between euro and Albanian leke, $P_{i}^{*}$ is the price level of the $\quad i^{\text {th }}$ country and the $W_{i}$ is the weight corresponding to the $i^{\text {th }}$ trade partner. According to this definition, a fall in the index will show a real overvaluation, and a increase will show a real depreciation of the domestic currency. Corresponding weights will be calculating through the formula:

$W^{i}=\frac{\left(X^{i}+M^{i}\right)}{\sum_{i=1}^{I}\left(X^{i}+M^{i}\right)}$

Where $X^{i}$ is the corresponding exports weight of $i^{\text {th }}$ country, $M^{i}$ is the corresponding import weight of the $i^{\text {th }}$ country where $\sum W^{i}=1$

Trade openness (OPEN), defined as the sum of exports and imports in relation to GDP. An increase in trade openness is considered as an indicator for reducing the trade restrictions. The aim of trade restrictions is the protection of domestic products. Reducing trade restriction, domestic products prices are expected to fall, leading to a depreciation of the RER. So, an increase in trade opening leads to the devaluation of the RER

Foreign Direct Investment (FDI) in relation to GDP will be used as a measure of financial globalization, as suggested by Xing and Zhang (2004). Elbadawi (1994) showed that an increase in inflows in the long run will result in appreciation of the real exchange rate in the long run. Elbadawi (1994) also showed that even in the short-term, inflows tend to be associated with the overvaluation of the real exchange rate in comparison with its value in the long run. Thus, foreign direct investmen ts have negative effect on the real exchange rate.

Remittances (REM) in relation to GDP: their effect on the real exchange rate is unclear. Remittances represent additions to the household income level. This will be accompanied by increasing demand for tradable and non -tradable products. While 
the prices of tradable products are determined in the world market, an increase in demand in the non-tradable sector will be accompanied by an increase in their price, to turn this sector again in balance. Thus, a relative increase in the price of no ntradable to tradable will lead to real exchange rate appreciation. Moreover, higher prices in this sector will lead to an increase in the supply in this sector, by transferring resources from the tradable sector to the non-tradable sector, reducing its activity. Reduce tradable sector activity will lead to falling exports and rising imports. Thu s the trade balance will deteriorate and the real exchange rate will depreciate.

Relative price of tradable to non-tradable (TNT), used to measure the Balassa-Samuelson (1964) effect. This effect explains the deviation from purchasing power parity (PPP). According to this effect, countries, which have relatively low productivity in tradable sector than in the non-tradable sector, should have lower prices than those, where this ratio is reversed. Thus, in these countries, productivity in the tradable sector will increase more rapidly than in the non-tradable sector. But, since the prices of tradable products for small countries are determined on the international market, productivity growth in the tradable sector will lead to wage growth in the economy. Wage growth will be accompanied by increasing the price of non-tradable sector. Since the real exchange rate is also defined as the ratio of the price of tradable to non-tradable products, an increase in the latter will lead to real exchange rate appreciation.

Real income per capita (PROD). Higher-income countries have higher price levels. This effect is known as "Penn Effect" (Summers and Heston, 1991). This means that there is a positive correlation between per capita real income and real exchange rate.

Government expenditure (GOV). The volume and composition of government spending affects the value of the real exchange rate. Edward (1989) showed that the increase in government spending causes an appreciation of the real exchange rate. While Ravna and others (2007) investigated the effect of government spending shocks for some industrial countries. They found that an increase in government spending leads to increased product and private consumption, a deterioration of the trade balance and a depreciation of the real exchange rate. Thus, the effect of the impact of government spending on the real exchange rate is unclear.

All the above variables will be used in the logarithm form. Considering these factors as determinants of the level of the real exchange rate and the expected impact of each of them, we can write the equation

$$
\begin{array}{cccccc}
- & + & +/- & + & - & +/- \\
\text { RER = f(TNT, OPEN, } & \text { REM, PROD, } & \text { FDI, GOV) }
\end{array}
$$

\section{ECONOMETRIC METHODOLOGY}

In this study will be used the cointegration method to explain the possibility of long-term relationship between economic variables. This method requires time series behavior testing before its application. Time series data usually serve to forecast variables behavior in the future. The main problem on regressing time series on another time series variable is the very high values of $R^{2}$ even though it may not have meaningful relationships between the dependent variable and independent variables. This situation usually is known as "spurious regression", which results mostly by the existence of a trend in the two time series, rather than a real connection between them.

Time series data will be tested to see if they are covariance stationary (i.e. no trend) or are stationary trend. This will be done through Augmented Dickey-Fuller test (ADF). If the exchange rate is not stationary, any stationary variable cannot be a determining variable because variables determining the exchange rate in the long run should have the same order of integration, as the exchange rate 
Table4.1 Summary of Unit Root Test

\begin{tabular}{|l|l|l|l|}
\hline Variable & ADF Test & p-value & Decision \\
\hline rer & -5.028596 & 0.0004 & Stationary \\
fdi & -3.239964 & 0.0285 & Stationary at 5\% \\
gdp & -3.597171 & 0.0124 & Stationary at 5\% \\
open & -6.367360 & 0.0000 & Stationary \\
rem & -8.580327 & 0.0000 & Stationary \\
tnt & -8.733748 & 0.0000 & Stationary \\
gov & -3.031379 & & Stationary at 5\% \\
& & & \\
& & & \\
\hline
\end{tabular}

Critical Values:

\begin{tabular}{|l|l|l|l|}
\hline & $\begin{array}{l}1 \% \text { Critical } \\
\text { Value }\end{array}$ & $\begin{array}{l}5 \% \text { Critical } \\
\text { Value }\end{array}$ & $10 \%$ Critical Value \\
\hline ADF Test & -3.689 & -2.971 & -2.625 \\
\hline
\end{tabular}

The test shows that FDI, PROD and GOV are not stationary, but become stationary after taking the First Difference. Thus, to eliminate the problem of stationary, variables should be included in the model in the first difference.

Cointegrating Test

This test serves to identify the possibility of a long-term relationship between real exchange rate and the fundamental variables determining the real exchange rate.

The table shows the results of cointegration test by using Johansen methodology. The result indicates rejection of the null hypothesis of lack of cointegration between variables and the existence of a cointegration equation in $5 \%$ level. So va riables have long-term relationships between them.

Table 4.2 Result of Johansen Cointegration Test

\begin{tabular}{lcccc}
\hline $\begin{array}{l}\text { Hypoth } \\
\text { esized } \\
\text { No. of } \\
\text { CE(s) }\end{array}$ & $\begin{array}{c}\text { Eigenva } \\
\text { lue }\end{array}$ & Statistic & $\begin{array}{c}0.05 \\
\text { Critical } \\
\text { Value }\end{array}$ & Prob.** \\
\hline \hline None * & 0.8599 & 137.74 & 125.61 & 0.0074 \\
At most 1 & 0.7604 & 84.667 & 95.753 & 0.2263 \\
At most 2 & 0.4716 & 46.080 & 69.818 & 0.7946 \\
At most 3 & 0.4349 & 28.855 & 47.856 & 0.7752 \\
At most 4 & 0.2965 & 13.440 & 29.797 & 0.8705 \\
At most 5 & 0.0723 & 3.9444 & 15.494 & 0.9080 \\
At most 6 & 0.0685 & 1.9172 & 3.8414 & 0.1662 \\
\hline \hline
\end{tabular}

Trace test indicates 1 cointegrating eqn(s) at the 0.05 level

* denotes rejection of the hypothesis at the 0.05 level

**MacKinnon-Haug-Michelis (1999) p-values

Unrestricted Cointegration Rank Test (Maximum Eigenvalue)

\begin{tabular}{ccccc}
\hline \hline & & Max- & & \\
Hypothesized & & Eigen & 0.05 & \\
& Eigenv & & Critical & \multirow{2}{*}{ Prob.** } \\
No. of CE(s) & alue & Statistic & Value & Pave \\
\hline \hline
\end{tabular}




\begin{tabular}{ccccc} 
None * & 0.859967 & 53.07864 & 46.23142 & 0.0081 \\
At most 1 & 0.760483 & 38.58653 & 40.07757 & 0.0729 \\
At most 2 & 0.471637 & 17.22524 & 33.87687 & 0.9128 \\
At most 3 & 0.434993 & 15.41476 & 27.58434 & 0.7148 \\
At most 4 & 0.296518 & 9.496240 & 21.13162 & 0.7905 \\
At most 5 & 0.072330 & 2.027146 & 14.26460 & 0.9901 \\
At most 6 & 0.068547 & 1.917264 & 3.841466 & 0.1662 \\
\hline
\end{tabular}

Max-eigenvalue test indicates 1 cointegrating eqn(s) at the 0.05 level

$*$ denotes rejection of the hypothesis at the 0.05 level

**MacKinnon-Haug-Michelis (1999) p-values

Thus, the cointegration vector in the equation form can be presented as:

LNRER $=1.3-0.76 \mathrm{LNFDI}+0.24 \mathrm{LNGOV}-0.0001 \mathrm{LNOPEN}-0.25 \mathrm{LNREM}+0.25 \mathrm{LNTNT}+0.002 \mathrm{LNGDP}$

We can see that trade openness and real income per capita are insignificant variables in our model. While an increase in Foreign Direct Investment appreciates real exchange rate. The coefficient is not very high: a $1 \%$ increase in FDI leads to real appreciation by $0.76 \%$. In terms of government spending, even though the coefficient in not high, we can say that $1 \%$ increase in government spending leads to real depreciation by $0.24 \%$. Similarly, a $1 \%$ change in remittances lead to an estimation by $0.25 \%$ of the real exchange rate. In terms of the ratio of tradable to non-tradable products, an increase of $1 \%$ on the value of this ratio leads to $0.25 \%$ depreciation of the real exchange rate.

\section{CONCLUSIONS}

This paper analyzed the model of real exchange rate determination in Albania, as a variable determined by fundamental macroeconomic variables. In this study were included in the model Foreign Direct Investment, real GDP per capita, the ratio of tradable to non tradable goods, Remittances, Openness and Government spending. Initially variables were tested for unit root. Some of the variables resulted stationary of order zero $\mathrm{I}(0)$, while the rest resulted stationary of the first order (I). To eliminate the problem of stationary, variables were entered in model in the first difference, then (I). Stationary variables were tested for cointegration: the possibility of the existence of a long-term relationship between them. The test showed the existence of an integration equation at $5 \%$.

The regression equation showed that real income per capita and trade openness do not have any significant impact on the real exchange rate in Albania. Other variables, an increase in foreign direct investment and remittances, tend to over valuate the real exchange rate and an increase in government spending and in the ratio of tradable to non-tradable tend to depreciate the real exchange rate in Albania

\section{REFERENCES}

Balassa, Bela, 1964, “The Purchasing Power Parity Doctrine: A Reappraisal,” Journal of Political Economy, Vol. 72, pp. 584-96.

ECB (2003)"Policy position of the Governing Council of the ECB on Exchange Rate Issues Relating to the Acceding Countries". European Central Bank, Frankfurt am Main (18th December 2003).

Edwards, Sebastian, 1989. "Real Exchange Rate, Devaluation and Adjustment", The MIT Press, Cambridge

Elbadawi, A.L (1994)." Estimating Long Run Equilibrium Real Exchange Rate" Institute for International Economics, Washington D.C

Frenkel, Roberto,2004. "Real Exchange Rate and Employment in Argentina, Brazil, Chile, and Mexico". Paper prepared for the Group of 24, Washington, D.C. September

HUA Ping,2011." The economic and social effects of real exchange rate_Evidence from the Chinese provinces" «INTERNATIONAL CONFERENCE ON SOCIAL COHESION AND DEVELOPMENT,2011, Paris, France OECD Development Centre. 
Kaminsky Graciela L. \& Carmen M. Reinhart, 1999.'The twin Crises:The causes of banking and balance of Payments Problems" American Economic Review. American Economic Association, vol. 89(3), pages 473-500, June.

Mancellari A.,Mytkolli H.,Kola T., 1999.’Kurset e këmbimit dhe tranzicioni ekonomik"

Ravn, M., S. Schmitt-Grohé and M. Uribe, 2007.” Explaining the Effects of Government Spending Shocks on Consumption and the Real Exchange Rate" NBER WP 13328.

Rodrik, Dani. 2008. "The Real Exchange Rate and Economic Growth: Theory and Evidence." Brookings Papers on Economic Activity, Fall Conference Draft.

Samuelson, Paul A., 1964, “Theoretical Notes on Trade Problems," Review of Economics and Statistics, Vol. 46, pp. 145-54.

Summers.Robert and Heston.Alan, 1991.”The Penn World Table: An Expanded Set of International Comparisons, 19501988”. The Quarterly Journal of Economics, MIT Press, vol. 106(2), pages 327-368, May.

Xing, Y. and Zhang, K.H (2004).” FDI and Regional Income Dis parity in Host Countries:

Evidence from Chin" Economia Internazionale Volume LVII, No. 3 - August 2004 